\title{
萧
}

\section{Genesis 20: A literary template for the prophetic tradition}

\author{
R. Gallaher Branch \\ School of Biblical Sciences \\ Potchefstroom Campus \\ North-West University \\ POTCHEFSTROOM
}

E-mail: sbbrgb@puknet.puk.ac.za

\begin{abstract}
Genesis 20: A literary template for the prophetic tradition

A close examination of Genesis 20 shows that the concept of prophet, which is mentioned for the first time in this chapter, is emphasised in three ways. First, God actively creates a new office - that of prophet. Second, he specifically gives a job description - that of intercessor. Third, he squarely sets in place a model - one that all subsequent prophets, prophetesses, and prophesies in some way follow and build upon. Significantly, Genesis 20 gives no indication that Abraham sought the designation of prophet or knew in advance it was coming. Abraham's new office emphasises God's sovereignty. Starting with Genesis 20, God establishes a pattern of maintaining for Himself the right first to choose Israel's prophets and later to choose its judges and kings. This article argues that Chapter 20 provides a ten-point foundation for the work of the prophet that the Hebrew Bible enlarges on in later books.
\end{abstract}

\section{Opsomming}

Genesis 20: 'n literêre sjabloon vir die profetiese tradisie

'n Noukeurige ontleding van Genesis 20 toon dat die konsep van profeet, wat vir die eerste keer in hierdie hoofstuk genoem word, op drie maniere benadruk word. Eerstens: God skep op 'n aktiewe wyse 'n nuwe amp - dié van profeet. Tweedens: God gee op 'n duidelike wyse 'n taakomskrywing - dié van voorbidder. Derders: Hy stel onmiskenbaar 'n model beskikbaar - een wat alle volgende profete, profetesse en profesieë in een of ander vorm navolg of daarop voortbou. Dit is belangrik om daarop te let dat Genesis 20 geen aanduiding gee dat Abraham 
die aanwysing as profeet nagestreef het of by voorbaat geweet het dat dit in die vooruitsig was nie. Abraham se nuwe amp benadruk God se soewereiniteit. Met Genesis 20 as beginpunt vestig God 'n patroon om vir Homself die reg voorbehou om Israel se profete te kies en later om die rigters en konings aan te wys. In hierdie artikel word betoog dat Hoofstuk 20 'n tienpuntgrondslag voorsien vir die taak van 'n profeet. Hierdie grondslag word in latere boeke van die Hebreeuse Bybel breër uitgewerk.

\section{Introduction}

Genesis 20 is the story of Abraham and Sarah's sojourn in Gerar, a city probably on the edge of Philistine territory in the Northern Negev near Gaza (Hudiberg, 2000:495). Abimelech rules the area. ${ }^{1}$ For the second time in the biblical record, the couple deceives their new neighbours by posing as full brother and sister. Although Abraham and Sarah are approximately 100 years old and 90 years old respectively, Sarah evidently is still a beautiful and desirable woman. Abimelech takes her into his household with the idea, it would seem, of having intercourse with her; but does not go near her, for God keeps him from doing so. God appears to Abimelech in a dream, rebukes him, and commands him to return Abraham's wife, "for he is a prophet and he will pray for you and you will live" (v. 7). Abimelech roundly rebukes Abraham for the deception, receives prayer, and loads Abraham up with gifts on account of Sarah. Evidently during the time the story takes place, the women in Abimelech's household experience fertility problems. The chapter ends by stating God heals them and they can have children again (vv. 17-18). 2

1 Abimelech is probably a generic Canaanite name meaning "My Father is Milku/King" (Wenham, 1994:70).

2 Commentators universally note Genesis 20's kinship with an incident in Genesis 12:10-20, a story that takes place about 25 years earlier in Egypt. Yes, both stories contain similarities. In both, Abram/Abraham and Sarai/Sarah, a childless couple married for a long time, pose as brother and sister. In both, Sarai/Sarah's beauty and Abram/Abraham's fear for his life because of it serve as reasons for their ruse. In both, innocent bystanders - the Egyptians in Pharaoh's household and those under Abimelech's rule in Gerar - experience the modern equivalent of medical emergencies. The Lord sends serious diseases to afflict the Egyptians, and he closes the wombs of those in Gerar (Gen. 12:17; 20:17-18). In both instances, an outraged ruler chastises Abram/Abraham. Pharaoh throws the couple out of the country, but Abimelech offers them settlement anywhere in his land, probably because he does not want to offend this new prophet. In both stories, Abram/Abraham prospers greatly with gifts from Pharaoh and from Abimelech because of his wife's amazing beauty. 


\section{Outline of scholarly views}

This article concentrates on the importance of Genesis 20:7, the first mention of a prophet in the biblical text, and on the context of the verse; it argues that the chapter offers both narrow and broad patterns of the phenomenon of prophecy in the biblical text. Over 40 percent of the Old Testament is narrative (Fee \& Stuart, 1993:78); the remainder of the biblical corpus contains an overwhelming percentage of poetry, and much of this poetry is considered prophecy. It is intriguing that the important biblical phenomenon called prophecy begins in a small way within the context of a domestic mess and an international scandal. Although Genesis 20 contains the Bible's first mention of a prophet, commentators for centuries have focused on its other aspects. A recap of scholarly views and insights on Genesis 20 follows.

\subsection{Rabbinic}

Rabbinic tradition ("Abimelech", 1971:2:76) credits Abimelech as a righteous Gentile. Aggadah, Jewish lore based on the biblical text, says that boils erupted on his skin and ruffians invaded his home because he took Sarah into his household ("Abimelech", 1971:2:76). Hamilton, however, disagrees with this tradition. He (Hamilton, 1995:71) argues that "only the restraining providence of God, rather than any moral vigor on Abimelech's part, deterred Abimelech from sleeping with Sarah". Wenham (1994:71) maintains the text emphasises God's omnipotent power to keep Abimelech from sinning against God.

\subsection{Early Church Fathers}

The Clementine Homilies (1951:viii:323), works attributed to Clement, sees Abimelech as a leader, impious in nature, who "wished to defile the wife of just Abraham by intercourse". The Clementine Homilies (1951:viii:323) groups Abimelech, the Pharaoh of Egypt during Joseph's time, and Nebuchadnezzer as examples of impious men to whom God sent dreams and visions. Therefore, "we cannot infer with absolute certainty that the man who has seen visions, and dreams, and apparitions is undoubtedly pious" (Clementine Homilies, 1951:viii:323). Clement himself also sees the example of Abraham and Sarah in Genesis 20 as presenting biblical teaching on children and marriage. Children of the same mother ought not to wed (Clement, 1951:ii:377, 503). Marriage should be for the sake of children and between those who are in every respect 
similar; in addition, the husband should not force his wife to love him (Clement, 1951:ii:377, 503).

Tertullian seeks to address the problem of Sarah's amazing beauty. Writing on the apparel of women, he (Tertullian, 1951:iv:19) stresses that Christian modesty is much desired over the carnal inclination of drawing attention to one's personal grace and form. Comeliness such as Sarah had is not to be censored, Tertullian (1951:iv:19) writes, as much as it is to be feared. Abraham in Gerar knew that his wife's beauty could incite "injuriousness and violence" and therefore he "greatly feared in regard of his wife's grace" (Tertullian, 1951: iv:19).

\subsection{Calvin}

Calvin goes to great lengths to make Abraham and Sarah cousins. Calvin (1948:2:525-526) argues that Abraham followed an accepted Old Testament tradition, namely, he "jumped generations"; Abraham cited his important forbearer when he explained to Abimelech that he and Sarah indeed were siblings after a fashion because they shared the same father but not the same mother (Gen. 20:12). Calvin (1948:2:525-526) corrects Abraham by clarifying that the patriarch actually meant grandfather and not father.

\subsection{Critical}

Skinner (1930:315) views Genesis 20 as "two variants of the same tradition"; he (Skinner, 1930:318) notes that marriage to a half-sister on the father's side was frequent among the Semites of the period. Heschel (1955:493) in his classic work The Prophets mentions Genesis 20 only twice. Taking a broad scope he (Heschel, 1955: 484) asserts that mankind's relevance to God and God's concern for mankind are the joint themes of all the prophets' work. Heschel instead concentrates on themes the prophets stress like judgment and chastisement.

Zimmerli (1978:174-175), one who favours the documentary hypothesis approach, sees the narrative of Genesis 10-50 - as the work of Zimmerli (1978:175) notes - that $J$ (the Yahwist) portrays Abraham and the other patriarchs in realistic terms; the stories about Abraham show his anxiety, for example, a very human trait. Von Rad (1962:I:292) writes that intercession, starting with Abraham in Genesis 20, was "the prophet's office par excellence in olden times" (italics included). Opting for a late date in writing Genesis, Von Rad (1965:II:12) argues that the titles of prophet given to Abraham (Gen. 
20:7), Moses (Deut. 18:15; 34:10), Aaron (Ex. 7:1), and Miriam (Ex. 15:20) should be taken as representing the way in which a much later age looked upon these people. Eichrodt (1961:l:282-283) observes that Genesis 20 shows that Yahweh occasionally intervenes when individuals like Abraham are not guiltless; another case is Jacob's actions toward Esau (Gen. 27 f.). Amazingly, religious truths can be conveyed via stories about ethically impure people (Eichrodt, 1961:l:284).

\subsection{Post-critical}

Modern commentators tend to follow Hamilton (1995:59) and Wenham (1994:75) and see Genesis 12 and 20 as having similarities but as two separate incidents and stories. Hamilton (1995:59) writes that the text gives the impression that the episode in Egypt was well planned and carefully thought through by Abram, while the episode in Gerar reads as a more spontaneous event. From their writings one can conclude that it is incredible but quite likely and altogether human that Abraham makes the same dreadful mistake twice! Biddle (1990:599-600) associates the theology of Genesis 20 with "J", but Blenkinsopp (1984:64) associates it with "E". Brueggemann (1982: 178), with typically keen insight, notes the text shows a surprising preference for the underdog, Abraham, the man clearly in the wrong in the story and the one who lies.

\subsection{Methodology for this article}

While Genesis 12:10-20 may inaugurate a pattern for repeating the brother/sister ruse in Genesis 20 and Genesis 26:1-11, Genesis 20, however, also presents the foundation for other patterns involving prophets and prophecy. This article follows Childs (1985:6-15) in taking a canonical approach to the chapter and Fokkelman (1975:18) in attitude. Fokkelman (1975:8) advises approaching a text like Genesis 20 carefully but with an attitude of confidence, expecting to find within the text itself keys to its understanding. Using Childs' methodology 3 and bearing in mind revelation history, this article

3 Childs (1985:11-15) offers several tenets of the canonical approach. In the first place it allows one to reflect theologically on the text as it has been received and shaped. Second, the final form of canonical literature, which we call the Bible, reflects a very long history and process of development that is marked and shaped by hundreds of unrecorded decisions. Third, the canonical approach sees the discipline of Old Testament theology as combining both descriptive and constructive features. In other words, it affirms the descriptive task of correctly interpreting the part of the text under consideration by acknowledging the text's place in Israel's faith, and it likewise understands that theological investigation also means the modern interpreter must take a stand regarding the text. Fourth, 
argues that Genesis 20 is a profound introduction to the prophetic tradition. It takes a synchronic approach to the chapter. 4 It sees Genesis 20 as containing a three-part action by God. First, God actively creates a new office - that of prophet. Second, he succinctly gives a job description - namely intercession. Third, he squarely sets in place an order and model that subsequent prophets, prophetesses, and prophesies follow and build upon.

\section{Ten aspects of Genesis 20 that set a template for the prophetic tradition}

This article considers ten aspects of Genesis 20 that set, within the context of revelation history, a template for the prophets' work in both testaments.

\subsection{The Bible presents prophecy as God's idea}

First, the Bible clearly presents prophecy as God's idea. Prophecy is in keeping with the biblical principle already well established in Genesis that all good things originate with God; for example, God originates creation and declares it good (Gen. 1:31). Prophecy is first mentioned by God in Genesis 20:7. Speaking to Abimelech in a dream God says, "Now return this man's wife for he is a prophet and he will pray for you" (italics added). True, prophecy was a phenomenon in the ancient Near East, and according to findings like the archives of Mari apparently was common among the Mesopotamian people with whom Abraham and Sarah lived (Van der Toon, 2000:71). The Hebrew Bible later likewise recognises that prophecy is not confined to Israel. Jeremiah 27:1-15 refers to prophets and other religious specialists from the neighbouring lands of Edom, Moab, Ammon, and the Phoenician cities (Blenkinsopp, 1984:54).

an interpreter taking a canonical approach acknowledges its flexibility; a canonical approach refrains from looking for a "single key" or a "missing link" that works for all biblical genres in interpretation. Fifth, a canonical approach acknowledges that the texts have become what we call scripture within the community of faith. Sixth, the canonical theologian accepts the canon as normative in the life of the Christian community. Finally, the theologian who favours a canonical approach acknowledges his or her need of illumination through the Holy Spirit for both the understanding of a text and its application.

4 I am grateful for various insights on this section to Profs. Herrie van Rooy and Hans van Deventer of the Faculty of Theology, North-West University, Potchefstroom Campus, South Africa. 
Starting with Abraham, however, the role of the prophet can be summarised succinctly as follows: the prophet in Israel spoke God's word for the immediate future (Tucker, 1987:170) and sometimes eschatologically for the more distant future. The true prophet does not originate or author his prophetic words; the instigation and origin of prophecy remain God's right and God's idea. Indeed, the prophet "is no more than an instrument by means of which the word is made known and spread" (Rofe, 1997:62). Furthermore, the ancients un a prophet as a man of God (Skinner, 1930:317).

In addition, Abraham and subsequent prophets were not theologians; however, starting with this patriarch, the prophets shared the same basic assumptions about God's character and developed the same themes. In other words, they knew the same God. For example in their various ways, they stressed that God expected justice and righteousness immediately. They proclaimed a unified message, one that held out hope to Israel (Clements, 1996:192193). In addition they announced, as prophetic heralds, God's intention of acting in the near future (Tucker, 1987:170). Prophecy later came to be associated with this formula: "Thus says the Lord" (Rofe, 1997:61).

\subsection{God reveals Himself to someone outside the covenant}

Second, God reveals Himself to Abimelech, to someone outside the covenant. The revelation comes in a dream. God's intervention in human life via dreams was not uncommon in Genesis. In addition to Abimelech, Genesis records the dreams of Jacob (28:10), Laban (31:24), Joseph (37:5), Pharaoh's cupbearer and baker (40:5), and finally Pharaoh himself $(41: 1)$. Hamilton (1995:60) notes the text plainly shows that God's covenant people do not have a monopoly on revelation from God. Blenkinsopp (1984:56) adds that among the Hittites, a people known in the time of Abraham, the priesthood exercised control over divination and dreams. But in Genesis, dreams of those in the covenant and outside the covenant fall under God's sovereignty. Furthermore, it would seem that to the ancients, events in dreams were as real as waking experiences (Skinner, 1930:316).

The biblical text records that God communicates with those outside the covenant through the prophets and often does so despite the prophets' resistance. For example, Jonah - with great reluctance and only after considerable godly persuasion in the form of a big fish - goes to Nineveh and preaches repentance. He succeeds in spite of himself, for Nineveh repents (Jonah 3:9-10). 
Jesus reaffirms this principle, the principle of seeking out others outside the covenant, in the New Testament. Jesus notes that no prophet is accepted in his hometown. Consequently, God sometimes sends a prophet where he is accepted - to the non-Israelites. Elijah, Jesus points out, was sent to a widow in Zarephath in the region of Sidon (1 Kings 17), and Naaman, the Syrian leper, obeyed Elisha's command and was cleansed (2 Kings 5) (Luke 4:24-27).

\subsection{Prophets routinely address community and national leaders}

Third, Genesis 20 establishes a pattern that prophets routinely talk with heads of state and religious leaders. Actually, the biblical text presents very few instances where a prophet is not directly involved with the head of state and concerned with the governing of the state (Holladay, 1987:125). The overwhelming records of prophetic words in the biblical text are to those directly associated with a royal court (Holladay, 1987:125). Consider the following examples: Moses pops in and out of Pharaoh's presence more than 10 times (Ex. 5:110:29). Isaiah, arriving unannounced at the palace while his friend, King Hezekiah, shows off the royal wealth to the emissaries from Babylon, suddenly prophesies that one day all that wealth will reside in Babylon (Isaiah 39). Jeremiah continuously has run-ins with King Zedekiah, but his message remains the same: Surrender to the Babylonians (Jer. 38:14-18). Amos and Amaziah contend in feisty arguments for who is the true prophet and who is the false prophet (Amos 7:10-17). Daniel interprets dreams for Nebuchadnezzer and later deciphers the mysterious writing on the wall for Belshazzar (Daniel 2; 5).

According to the understanding of those in the ancient Near East, a prophet was the official representative of the sender himself; Assyrian documents show the prophet stood in the court of the Great King (Holladay, 1987:123). In Israel, the prophet came to be a quasi-official in government and served as a continuing agent of God's rule in Israel (Holladay, 1987:125). The prophet represented God's day-to-day involvement and interest in the governing of Israel.

In the New Testament, Jesus meets with the Sanhedrin, Herod, and Pilate. He tells the high priest in the presence of the Sanhedrin, "You will see the Son of Man sitting at the right hand of the Mighty One and coming on the clouds of heaven" (Mark 14:62). 


\subsection{Prophets intercede}

Fourth, prophets pray. They intercede. God says to Abimelech, "Now return the man's wife, for he is a prophet, and he will pray for you and you will live" (Gen. 20:7) (italics added). The verb palal, pray, is in the Hithpael stem and refers to intercessory prayer (Hamilton, 1995:64). Since the text offers no explanation, it seems to assume that Abimelech is familiar with the concept of prophet (Hamilton, 1995:64). Abraham follows his job description: he obeys God and prays for Abimelech. Apparently his duplicity has not disqualified him from functioning as a prophet and intercessor (Hamilton, 1995:64). Abraham intercedes according to the will of God; and the will of God is consistent with the character of God. God responds by healing Abimelech, his wife, and his slave girls so they can have children again, "for the Lord had closed up every womb in Abimelech's household because of Abraham's wife Sarah" (Gen. 20:17). Jeremiah 27:18 later echoes Genesis 20:7 by saying, "If there are really prophets, and the word of the Lord is with them, let them intercede with the Lord of Hosts" (italics added).

Arguably, intercession remains a prophet's key function throughout the biblical text. When Miriam is stricken with leprosy, a punishment from the Lord for her jealous outburst against her brother Moses, Moses intercedes and she is healed (Numbers 12). Elijah prays for life to come back to the widow's son - and it does! This is an amazing miracle, the first resuscitation of life from the dead in the Bible. Elijah returns the lad to his mother. In choppy Hebrew, obviously spoken by a woman overwhelmed with wonder, joy, and thanksgiving, the widow exclaims, "Now I know that you are a man of God and that the word of the Lord from your mouth is the truth!" (1 Kings 17:24). Yet the text seems to assert that readers, hearers, Elijah, and the woman as well should not be surprised at all when life returns to the boy. Why? Because Elijah the prophet merely performs his job: intercession. And God responds affirmatively! Consistently in the biblical text God responds affirmatively when prophets do their job and act within the stipulations of their office. When prophets intercede, God acts. When prophets intercede, miracles happen. The pattern starts in Genesis 20 and continues in the New Testament. Jesus prays his famous prayer of intercession from the cross, "Father forgive them, for they know not what they do" (Luke 23:34). 


\subsection{God responds to a crisis via the prophetic word}

Fifth, God responds to a crisis via the prophetic word. In Genesis 20, Abraham creates a crisis of his own making. The crisis involved here is that of covenant: God promised Abraham a son and heir from his own body (Gen. 15:4); furthermore, he promised Sarah a son "next year" (Gen. 18:14). If the biblical text from Genesis 18 through 20 faithfully reflects a chronological order (and scholars think it does; see Wenham, 1994:40, 75), then Sarah must become pregnant within a year by her husband Abraham and not through Abimelech.

But Abimelech sees Sarah as an available and still beautiful woman - even at age 90. Abimelech points out to God that he took Sarah with a clean conscience (Gen. 20:5). God agrees. God then tells Abimelech three things. First, what to do to get out of the crisis: return the man's wife. Second, what will happen if he does that: he will live. Third, what will happen if he does not return Sarah: "You may be sure that you and all yours will die" (Gen. 20:7). Very often the prophetic word presents a choice between death and life. Very frequently in subsequent prophetic words a message of doom is followed by a word of salvation (Clements, 1996:202). Stated a slightly different way, prophecy from Genesis 20 on links predicting the future with a justification for its outcome (Rofe, 1997:61).

Prophecies frequently follow this formula throughout the Bible: stating the problem, stating the solution, and stating what will happen if the solution is not followed. For example, when an army of Moabites, Ammonites, and Meunites surrounds King Jehoshaphat and the people of Jerusalem, they seek the Lord. The prophetic word tells the people what to do: Be not afraid, be not discouraged, for the battle is not yours but God's (2 Chron. 20:15). The people obey. They march out and come to a battlefield already littered with the corpses of their would-be assailants! Their enemies had attacked and slaughtered each other. The people of Judah and Jerusalem haul off their enemies' loot for three days (2 Chron. 20:25).

\subsection{Prophecy foretells and forthtells}

Sixth, prophecy both foretells and forthtells. By foretelling, prophecy says what will happen in the immediate future. In Genesis 20, God tells Abimelech that he will surely die if he refuses to release Sarah (verse 7). Prophecy also forthtells: it broadly specifies God's will on a situation. In this Genesis story, God declares his willingness to heal. God heals the crisis of infertility affecting Abimelech, his wife, 
and his slave girls. This crisis had been Abimelech's punishment for taking Abraham's wife (Gen. 20:17). Throughout the biblical text this principle holds: God, as his character expressed in words and deeds shows, works toward life.

Forthtelling is more common than foretelling in the biblical text, although the two often combine in one as in the case of eschatological prophecies, prophecies about the end times. Prophecy as forthtelling shows God's broad plans. In the Genesis story, God keeps Abimelech from sinning against him by committing adultery by keeping him from Sarah. God clearly wants Abimelech and his household to live. God as a God of life is a consistent biblical principle.

\subsection{God works on the prophet's character}

Seventh, the biblical text provides ample evidence that God works simultaneously on the prophet's character even as the prophet acts as God's spokesperson. Sometimes this involves correcting a prophet while the prophet is on the job. Genesis 20 shows the clay feet of the righteous but all-too-human prophet who a short time earlier boldly had pleaded for the salvation of Sodom. Genesis 20 now describes Abraham's less-than-perfect trust in God's safekeeping (Wenham, 1994:75).

Abimelech clearly upbraids Abraham for his wilful deception. He chastises Abraham for going against the conventional code of morals (Skinner, 1930:318). The "great sin" in the ancient Near East is adultery (Hamilton, 1995:67). Speaking in anger, he gives the first prophet one of the severest tongue-lashings recorded in scripture: "What have you done to us? How have I wronged you that you have brought such great guilt upon me and my kingdom? You have done things to me that should not be done!" (Gen. 20:9). The book of Jonah also can be read as ways in which God corrects Jonah's attitudes towards those outside the covenant and points out Jonah's unjustified anger (Jonah 4:4, 9). Whereas Abraham gets a tongue lashing from Abimelech, the tables turn later on. Prophets most frequently upbraid kings, princes, priests and false prophets (Heschel, 1955:479-480).

\subsection{Prophecies are given orally}

Eighth, prophets were originally not writers but speakers (Gunkel, 1987:24); most prophecies are first given orally and then written down. This holds true throughout the biblical text. Exceptions include 
the prophet Elijah's letter to Jehoram (2 Chron. 21:12-15), Jeremiah's letter to the exiles in Babylon (Jer. 29:1-23), and the Book of Revelation.

\subsection{Prophecy usually affects many people}

Ninth, a prophecy, though often given to an individual, may affect many more people or even a nation. God's word to Abimelech concerned his household and his kingdom. After Abraham has prayed, the barren Philistine women again are able to conceive (Hamilton, 1995:71). Consider these other examples. On God's command, Moses confronts Pharaoh numerous times with the Lord's command to Pharaoh to "let my people go so that they may hold a festival to me in the desert" (Ex. 5:1). Pharaoh refuses. The consequence? Judgment. Plagues beset the land of Egypt and devastate it. Elijah addresses Ahab with the shocking news that "As the Lord, the God of Israel lives whom I serve, there will be neither dew nor rain in the next few years except at my word" (1 Kings 17:1). This drought leads to a famine that afflicts a large number of people.

\subsection{Other possible patterns in Genesis 20}

Genesis 20 also raises the possibility of additional patterns. One such pattern is preparation. The earlier stories about Abraham starting from when he is introduced as Abram in Genesis 11:29 arguably show how circumstances and his responses to them prepared him for the job of prophet. In Genesis 12 Abram hears God's call to leave his homeland and obeys (vv 1, 4). In Genesis 18 he pleads - intercedes - for Sodom and Gomorrah before the Lord (vv. 18-33); Abraham shows himself skilled in intercession (Blenkinsopp, 1984:62). Here in Genesis 20, he receives the job description of "exactly the role ascribed to him" in Chapter 18 (Wenham, 1994:75). Consequently, hearing the voice of God, acting in obedience, and interceding for others prefigure his designation as prophet in the biblical text. The biblical text records stories relating to the preparation of Moses, Samuel, Jeremiah, and Jesus as prophets, but records nothing about their early life or their preparation for the job for the majority of prophets. Instead, they erupt on the text much like Elijah enters the text, a full-blown prophet giving explosive words to Ahab (1 Kings 17:1).

Two other possible patterns in Genesis 20 are that prophets are only old and are only men. The biblical text quickly refutes these possibilities. God's choice of the boy Samuel breaks this pattern that 
prophets are only old; his choice of prophetesses like Miriam and Deborah shows prophecy is not dominated by men (1 Sam. 3:19-20; Ex. 15:20; Judges 4:4). The Rabbis declare the Hebrew Bible contains 144 male prophets - but do not name them; they do, however, list and name seven prophetesses: Miriam, Abigail, Huldah, Ruth, Hannah, Esther, and Deborah (Babylonian Talmud. Megillah, 139:71).

Another possible pattern based on Abraham's life is that prophets live long lives, accumulate lots of wealth, and die a natural death. Abraham died a very wealthy man at age 175 (Gen. 25:5-7); his two sons Isaac and Ishmael buried him (Gen. 25:9). Isaiah, however, probably fared differently. Jewish tradition says that King Manasseh ordered his father's friend Isaiah sawn in half (Trafton, 1992:III:507). Jewish tradition also says Jews in Egypt killed the prophet Jeremiah (Lunborn, 1992:690). Jesus, acclaimed as a prophet (Acts 3:22), died on the cross.

A minor tradition does start with Abraham, however, the tradition of being called a prophet or prophetess but not having any of your prophecies recorded in the biblical text or attributed directly to you. In addition to Abraham, Miriam follows this pattern. Stories after Genesis 20, however, show Abraham's growth as a prophet. Although Abraham's later words lack the formula phrase, "Thus says the Lord" favoured by so many prophets who follow him, his words nonetheless carry prophetic overtones. In Genesis 22 as Abraham and his son Isaac walk up the hill to offer a sacrifice, Isaac asks a pertinent question: "Where is the lamb for the burnt offering" (v. 7). Abraham answers, "God himself will provide the lamb for the burnt offering, my son" (Gen. 22:8). And in Genesis 24 Abraham announces to his servant that God will send his angel in advance so that the servant can find a wife for Isaac among Abraham's kin (v. 7).

\subsection{The tenth pattern, God's sovereign choice}

A pattern, the tenth, that the biblical text definitely substantiates, however, is that of sovereign selection, God's unexplained choice. The text in Genesis fails to say if God consulted Abraham about his new job. Indeed, the job may have come as a complete surprise to him. Indeed, Abraham may not have wanted to be a prophet. God's announcement that Abraham is a prophet indicates a promotion of sorts. The biblical text includes prophets as members of the heavenly council (Jer. 23:9 ff.) (Holladay, 1987:123-124; Wenham, 1994:69). 
As a prophet, Abraham becomes the instrument of God's will whether he wants to be or not. The relationship between prophet and God is that of servant/slave and master. The prophet comes to function something like a herald and at times the distinction between the prophet and God becomes blurred (Rofe, 1997:61).

Later biblical tradition (i.e., Moses and Jeremiah) indicates, however, that Abraham probably had no choice about his promotion to prophet. For example, Moses cries out, "Oh, Lord, please send someone else to do it!" (Ex. 4:13). Jeremiah cries out, "Ah, Sovereign Lord, I do not know how to speak. I am only a child" (Jer. 1:6). The text indicates the Lord makes short work of arguments like these.

This concept of not wanting to be a prophet changes in the New Testament. It seems that with Pentecost, the office of prophet becomes available to those who, in Paul's words, pursue prophecy. Paul writes in 1 Corinthians 14:1-5 that yes, follow the way of love outlined so eloquently just before in 1 Corinthians 13 , but by all means desire spiritual gifts, especially the gift of prophecy. Why? Paul answers that prophecies speak to men for their strengthening, encouragement, and comfort (1 Cor. 14:3). Prophecies build up the church. Paul writes that he would like everyone to prophesy because prophecy builds up its hearers.

In this way, the concept of prophecy in the biblical text comes full circle. Prophecy, with its origin in Genesis 20, carries on the concept that good gifts originate with God. In Genesis 20, there was one prophet. By 1 Corinthians 14, there is the command to all believers to pursue this good gift.

\section{Conclusion}

So far, this article has looked at Genesis 20 narrowly. However, the chapter also invites scrutiny in a broader sense. Beginning in Genesis 20, the prophetic word intrudes into history. It certainly intruded into the lives of Abraham, Sarah, Abimelech, and the people of Gerar. This small chapter about Abraham and Sarah's second marital deception serves as a template or pattern for subsequent prophecies and subsequent prophets and prophetesses. As a template, Genesis 20 in a broad sense speaks against the hopelessness of the human condition; it fights against the despair caused by barrenness, sin, illness, catastrophe, or whatever. The prophetic word shows God cares, God listens, God hears, God acts, God intervenes. The prophetic word defies the views that 
humankind must resign itself to fate, that everything is predetermined and absolute, that history is a closed process. Likewise it speaks against the view that human choice does not matter (Brueggemann, 2000:35). Instead, the prophetic word brims with life and possibilities. A new door has opened. The prophetic word presents a new perspective.

Since the prophetic word most frequently comes unexpectedly, it often stuns and surprises its recipients (Brueggemann, 2000:36). Yet its broadness (and some would say vagueness) allows for personal growth and for history to unfold. Very often the prophetic word lacks the specifics we as human beings long for. In Genesis 20, for instance, God does not say when or how or how he will heal Abimelech's household. He simply says he will - if Abimelech meets the conditions of returning the prophet's wife. The prophetic word customarily leaves the details like when, how, how many, where, and why up to God. Although frequently sparse, the prophetic word evidently gives all that needs to be known. At least it gives all that God chooses to reveal.

The prophetic word demands a response. The prophetic word calls upon its hearers to trust the messenger, the message, and above all the One who sent the messenger. In Genesis 20 Abimelech must return the man's wife in order to live; in addition, Abimelech must submit to Abraham's prayer. Abraham's response is that he must pray. This action probably involves humbling himself in front of the one he lately had wilfully deceived. Actually, probably neither man liked interacting with the other at this time in the story. After Abraham has prayed, the people of Gerar must resume their normal lives so that fertility will result in the normal way.

The prophetic word allows for miracles. Actually, the prophetic word celebrates miracles. The prophetic word expects miracles. Indeed, nothing is too hard, too difficult, to wondrous, too impossible for God (Gen. 18:14) (Brueggemann, 2000:36). The prophetic word decrees and expects the wondrous. The prophetic word confesses God's work in history and humanity. "While our fearful human propensity is to close down the historical prospect, it is the work of this God and the speech of this God that keep the historical horizon open," Brueggemann (2000:37) writes.

Very often the message of a prophet is restoration (Clements, 1996:194). Genesis 20 hints at this pattern, too. Restoration, as it expands in the biblical text as part of revelation history, turns out to be a flexible concept expressed frequently among the Hebrew Bible 
prophets; gradually in the biblical text it turned into messianic expressions (Clements, 1996:194). Restoration points to God's goodness and God's holiness.

The voice of the prophet, while it may sound strident and critical, really at its root encourages. From Genesis 20 on as part of revelation history, prophetic speech becomes "an act of relentless hope that refuses despair" (Brueggemann, 2000:40). The hope is in the One behind the prophetic voice itself. Speaking narrowly for Genesis 20, Abraham's prophetic word and its resultant restoration of fertility to Abimelech's household must have encouraged both Abraham and Sarah about their own childless condition. Speaking broadly, the prophetic word in Genesis 20 addresses human suffering and seeks to end it. It seeks to end the suffering caused by barrenness and to restore fertility. While the prophetic word may rebuke strongly (see Amos 1, 2, 3, 4; Is. 5:1-7; Dan. 4:1-27), it also beseeches people to repent and thereby to avert or delay an upcoming punishment (see 1 Kings 21:27-29; Jer. 15:19). The voice of the prophet loudly proclaims, as Isaiah puts it so well, "See, I am doing a new thing" (Is. 43:19). The voice of the prophet loudly calls on people not to forget God (Rofe, 1997:56). The prophetic word from Genesis 20 on truly acts as a life-giving exclamation point.

\section{List of references}

"ABIMELECH”. 1971. Encyclopaedia Judaica. Keter: Jerusalem, 2:76.

BABYLONIAN TALMUD. 1939. Megillah. London: Soncino.

BIDDLE, M.E. 1990. The 'endangered ancestress' and blessing for the nations. Journal of Biblical Literature, 109: 599-611.

BLENKINSOPP, J. 1984. A history of prophecy in Israel: From the settlement in the land to the Hellenistic period. London: SPCK.

BRUEGGEMANN, W. 1982. Genesis. Atlanta: John Knox.

BRUEGGEMANN, W. 2000. Texts that linger, words that explode. Minneapolis: Fortress.

CALVIN, J. 1948. Commentary on the Book of Genesis. Vol. 2. Grand Rapids, MI: Eerdmans.

CHILDS, B.S. 1985. Old Testament theology in a canonical context. Philadelphia: Fortress.

CLEMENT. 1951. The ante-Nicene Fathers. (In Roberts, A. \& Donaldson, J., eds. Translations of the writings of the Fathers down to A.D. 325. Vol. II. Fathers of the second century: Hermas, Tatian, Athenagoras, Theophilus, and Clement of Alexandria (Entire). Grand Rapids, MI: Eerdmans. p. 163629.) 
CLEMENTINE HOMILIES. 1951. The ante-Nicene Fathers. (In Roberts, A. \& Donaldson, J., eds. Translations of the writings of the Fathers down to A.D. 325. Vol. VIII. The twelve patriarchs, excerpts and epistles, The Clementina, Aprocrypha, Decretals, Memoirs of Edessa and Syriac Documents, Remains of the First Ages. Grand Rapids, MI: Eerdmans. p. 215-346. )

CLEMENTS, R. E. 1996. Old Testament prophecy: from oracles to canon. Louisville, KY: Westminster John Knox.

EICHRODT, W. 1961. Theology of the Old Testament. Vol. 1. Trans. by J.A. Baker. London: SCM.

FEE, G.D., \& STUART, D. 1993. How to read the Bible for all its worth. Grand Rapids, MI: Zondervan.

FOKKELMAN, J.P. 1975. Narrative art in Genesis: Specimens of stylistic and structural analysis. Amsterdam: Van Gorcum, Assen.

GUNKEL, H. 1987. The prophets as writers and poets. (In Petersen, D.L., ed. Prophecy in Israel. Philadelphia: Fortress. p. 22-73.)

HAMILTON, V.P. 1995. The Book of Genesis: Chapters 18-50. Grand Rapids, $\mathrm{MI}$ : Eerdmans.

HESCHEL, A.J. 1955. The Prophets. New York: Harper \& Row.

HOLLADAY, J.S., Jr. 1987. Assyrian statecraft and the prophets of Israel. (In Petersen, D.L., ed. Prophecy in Israel. Philadelphia: Fortress. p. 122-143.)

HUDIBERG, A.H. 2000. Gerar. (In Freedman, D.N., Myers, A.C. \& Beck, A.B., eds. Eerdmans dictionary of the Bible. Grand Rapids, MI: Eerdmans. p. 495.)

LUNBORN, J.R. 1992. Jeremiah. (In Freedman, D.N., ed. Anchor Bible dictionary III. New York: Doubleday. p. 685-689.)

ROFE, A. 1997. Introduction to the prophetic literature. The Biblical Seminar 21. Translated from the Hebrew by J.H. Seeligmann. Sheffield, England: Sheffield Academic Press.

SKINNER, J. 1930. The international critical commentary: A critical and exegetical commentary on Genesis. 2nd ed. Edinburgh: Clark.

TERTULLIAN. 1951. The ante-Nicene Fathers: Translations of the writings of the Fathers down to A.D. 325. (Roberts, A. \& Donaldson, J., eds. Vol. IV. Tertullian, Part Fourth; Minucius Felix; Commodian; Origen, Parts first and second. Grand Rapids, MI: Eerdmans. p. 5-166.)

TRAFTON, J. 1992. Isaiah, martyrdom and ascension of. (In Freedman, D.N., ed. Anchor Bible dictionary III. New York: Doubleday. p. 507-509.)

TUCKER, G.M. 1987. The role of the prophets and the role of the church. (In Petersen, D.L., ed. Prophecy in Israel. Philadelphia: Fortress. p. 159-174.)

VAN DER TOON, K. 2000. Mesopotamian prophecy between immanence and transcendence: A comparison of old Babylonian and neo-Assyrian prophecy. (In Nissinen, M., ed. Prophecy in the Ancient Near Eastern context: Mesopotamian, Biblical, and Arabian perspectives. Atlanta: Society of Biblical Literature. p. 71-87.)

VON RAD, G. 1962. Old Testament theology. Vol. I. The theology of Israel's historic traditions. Trans. by D.M.G. Stalker. Edinburgh/London: Oliver Boyd.

VON RAD, G. 1965. Old Testament theology. Vol. II. The theology of Israel's prophetic traditions. Trans. by D.M.G. Stalker. Edinburgh/London: Oliver Boyd. 
WENHAM, G.J. 1994. Genesis 16-50. Vol. 2. Waco, TX: Word.

ZIMMERLI, W. 1978. Old Testament theology. Trans. By D.E. Green. Edinburgh: Clark.

\section{Key concepts:}

Abimelech

Abraham and Sarah

Biblical narration; patterns

Genesis 20

prophecy and prophets

\section{Kernbegrippe:}

Abimeleg

Abraham en Sara

Bybelse narratief; patrone Genesis 20

profesie en profete 